\title{
Delayed Ripening of Climacteric Fruit by Catalysts Prepared from Induced Cells of Rhodococcus rhodochrous DAP 96253: A Case for the Biological Modulation of Yang-Cycle Driven Processes by a Prokaryote
}

George E. Pierce, Trudy A. Tucker, Cui Wang,

Katie Swensen, and Sidney A. Crow, Jr.

Applied \& Environmental Microbiology, Department of Biology, Georgia State University, Atlanta, GA

\begin{abstract}
Induced cells of Rhodococcus rhodochrous DAP 96253, when placed in the proximity of climacteric fruit (peaches, bananas, avocados) delay the ripening of the fruit. Examination of the delayed ripening shows that the induced cells possess multiple mechanisms that have the potential to impact the Yang Cycle in climacteric plants and processes such as volatile flavor and fragrance compounds related to the climacteric process. The suggestion is brought forward that these induced R. rhodochrous cells possess the ability to modify/modulate an important plant process.
\end{abstract}

\section{Introduction}

7 his review provides a current summary of our work regarding the delayed ripening of climacteric fruit by induced cells of Rhodococcus rhodochrous DAP 96253. In the process of developing this technology, we believe a picture is emerging that illustrates a close relationship between the Yang Cycle, its role in climacteric plants (Fig. 1), and the biochemistry/physiology of an induced environmental prokaryote. ${ }^{1}$

The role of communication (plant signaling) in the ripening of climacteric fruit or in the response of climacteric fruit to chill injury is well established. ${ }^{1-4}$ Equally well established is the complex intraspecies communication present in a number of plant diseases such as Dutch elm disease or Ambrosia fungi/ beetles. In all of these communication schemes, volatile organic compounds play an important role.

Our investigation of nitrile/amide metabolism in nature led to the discovery that induced cells of $R$. rhodochrous strain DAP 96253, when placed in proximity to harvested peaches (Fig. 2), significantly delays ripening. ${ }^{5-7}$ Subsequent studies showed delayed ripening of yellow bananas (Fig. 3) and avocados. Studies conducted with numerous peach varieties grown in the state of Georgia showed that delaying the ripening of peaches also delayed the onset of mold growth (Fig. 2 ) ${ }^{5-8}$ It was also observed that the effects of chill injury in peaches, after extended periods of refrigeration at transport temperatures recommended by the United States Department of Agriculture, could be significantly mitigated by exposing the refrigerated peaches to induced cells of $R$. rhodochrous DAP $96253 .^{8}$

Initially, all experiments were conducted using live cells of induced $R$. rhodochrous DAP 96253. But, to investigate practical methods, the cells were immobilized using glutaraldehyde and then cross-linked using polyethylenimine (PEI), a method that renders the cells non-replicating. ${ }^{8-11}$ While no viable cells could be recovered from glutaraldehyde/PEI immobilization, the immobilized cells were still capable of delaying the ripening of peaches and/or bananas. ${ }^{5-8}$

\section{Materials and Methods MICROORGANISMS}

The bulk of the delayed ripening work was conducted using $R$. rhodochrous DAP 96253. The maintenance, cultivation, and induction are detailed in Pierce et al. ${ }^{8-11} R$. rhodochrous DAP 96253 cells were grown on yeast extract, malt extract agar (YEMEA) medium (ISP medium 2 as recommended by Dietz and Thayer). ${ }^{12}$ Full induction was achieved by supplementing YEMEA with urea $(7 \mathrm{~g} / \mathrm{L})$ and cobalt $\left(\right.$ as $\left.\mathrm{CoCl}_{2}\right)$, at $10-88 \mathrm{ppm}$ with $50 \mathrm{ppm}$ preferred. ${ }^{5} R$. rhodochrous DAP 96622 was similarly maintained. Rhodococcus erythropolis 47072 was obtained from the American Type Culture Collection (ATCC, Manassas, VA), and was initially revived and maintained as recommended by the ATCC before transfer to YEMEA-based media.

$R$. rhodochrous DAP 96253 has been deposited with the ATCC and has been subsequently assigned the strain designation ATCC 55889.

\section{ENZYME ASSAYS}

Nitrile hydratase. $R$. rhodochrous DAP 96253 cell concentrate (equivalent to $50 \mathrm{mg}$ ) was first suspended with $1 \mathrm{~mL} 50 \mathrm{mM}$ phosphate buffer (pH 7.4) and then diluted to $50 \mathrm{~mL}$ with the phosphate buffer. Sufficient cell suspension was prepared for all enzyme assays to be conducted in triplicate using identical cell suspensions. The method is based upon the method of Pierce et al., as follows. ${ }^{8}$ Cell suspension $(1 \mathrm{~mL})$ is combined with $9 \mathrm{~mL}$ of acrylonitrile solution $(5,000 \mathrm{ppm}$ in phosphate buffer) and vigorously mixed for $2 \mathrm{~min}$ at $30^{\circ} \mathrm{C}$, at which time the reaction is terminated by the addition of $20 \mu \mathrm{L}$ of $4 \mathrm{~N} \mathrm{H}_{2} \mathrm{SO}_{4}$. After 


\section{PROKARYOTE-INDUCED DELAYED FRUIT RIPENING}

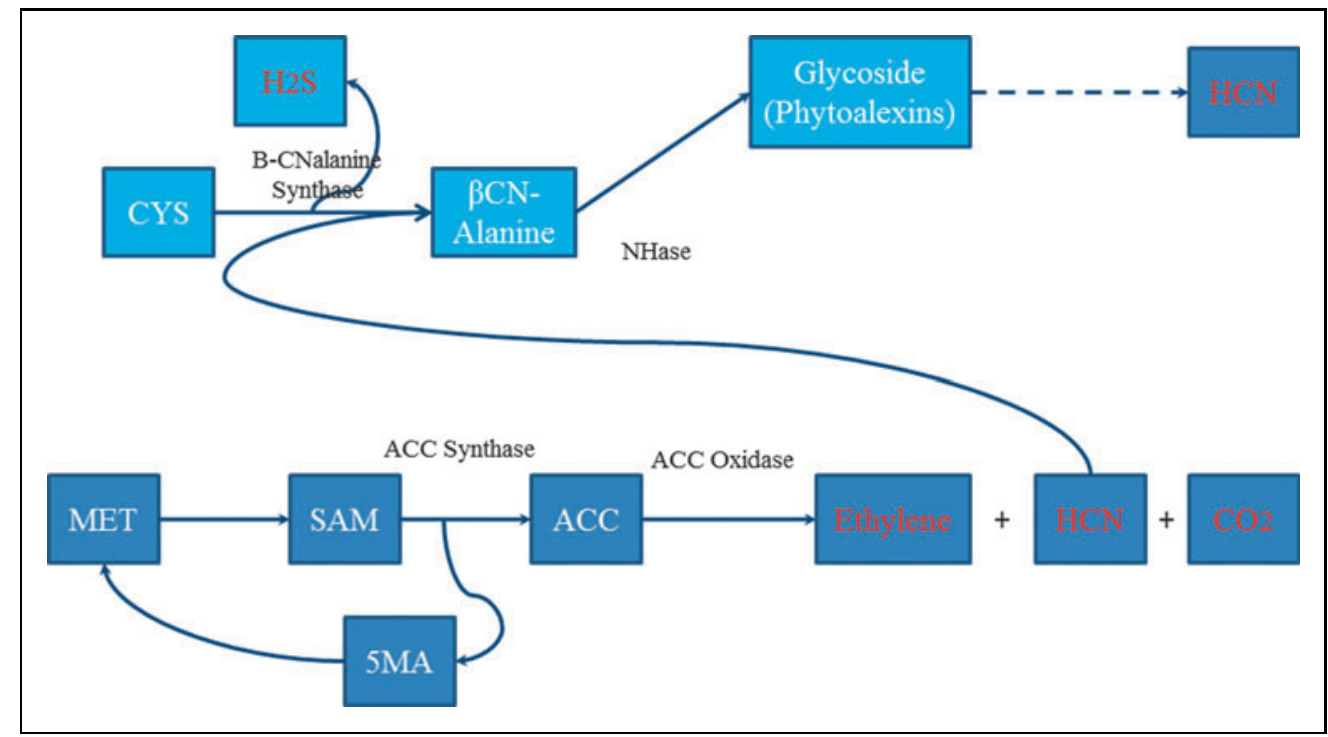

Fig. 1. Yang Cycle (dark blue boxes), including the integration of $\beta$-cyanoalanine synthase activity (light blue boxes); red text indicates compounds with defined volatility. ${ }^{1}$

mixing for $1 \mathrm{~min}$, the reaction was neutralized with $4 \mathrm{~N} \mathrm{NaOH}$. Cells were separated either by centrifugation or filtration, and 2.5 units of amidase (Sigma-Aldrich, St. Louis, MO) was added to the cell-free solution. The solution was then incubated for $30 \mathrm{~min}$ at $37^{\circ} \mathrm{C}$. The solution was transferred into a new test tube, and $2 \mathrm{~mL}$ sodium phenate, $3 \mathrm{~mL} 0.01 \%$ sodium nitroprusside solution, and $3 \mathrm{~mL} 0.15 \%$ sodium hydrochloride solution were added, in that order. (The phenate solution was prepared by melting $25 \mathrm{~g}$ phenol in a waterbath at $50^{\circ} \mathrm{C}$, followed by addition of $800 \mathrm{~mL}$ double distilled water and $78 \mathrm{~mL} 4 \mathrm{~N} \mathrm{NaOH}$.) The test

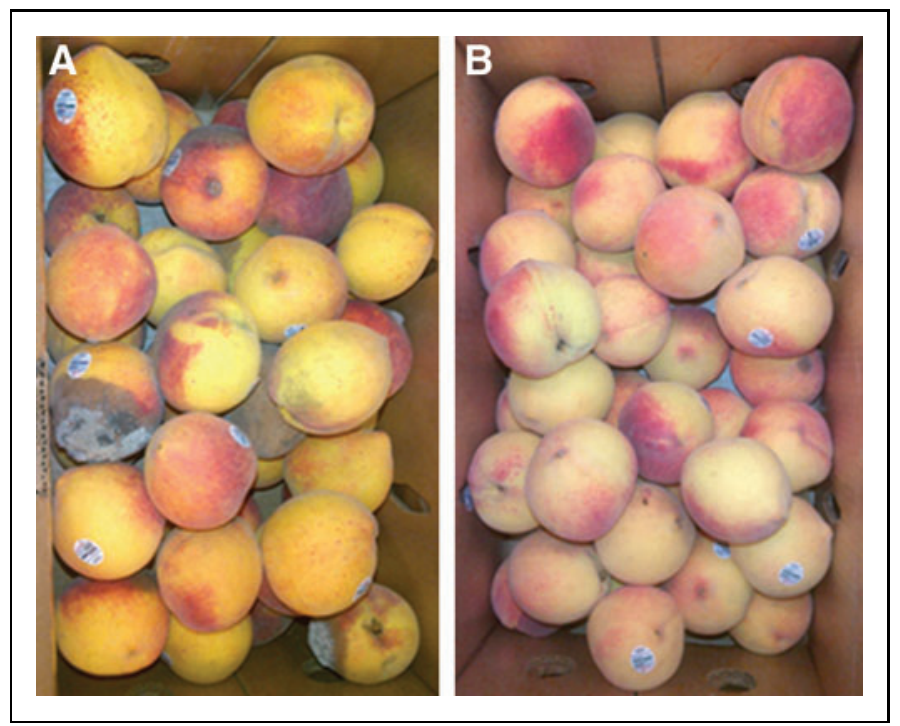

Fig. 2. Comparison of Big Red Peaches held for 6 days at $25-27^{\circ} \mathrm{C}$. (A) Control peaches; (B) peaches exposed to $R$. rhodochrous DAP 96253 (induced cell catalyst in an edible wax formulation applied to the inner cardboard surface of the box). tube was vortexed for $30 \mathrm{sec}$ and incubated in the dark at room temperature for $30 \mathrm{~min}$. After $30 \mathrm{~min}$, the optical density (OD) was measured at $600 \mathrm{~nm}$.

Amidase and cyanidase assays. Using the cell solution prepared above $(1 \mathrm{mg}$ cells $/ \mathrm{mL}), 1 \mathrm{~mL}$ of cell solution was added to $9 \mathrm{~mL}$ of acrylamide solution $(1,000 \mathrm{ppm}$ in phosphate buffer) for the amidase assay-or $9 \mathrm{~mL}$ of HCN solution (50 ppm in phosphate buffer) for the cyanidase assay. The solutions were vigorously mixed for $2 \mathrm{~min}$ at $30^{\circ} \mathrm{C}$, at which time the reactions were terminated by the addition of $20 \mu \mathrm{L}$ of $4 \mathrm{~N} \mathrm{H}_{2} \mathrm{SO}_{4}$. After mixing for $1 \mathrm{~min}$, the reactions were neutralized with $4 \mathrm{~N}$ $\mathrm{NaOH}$. Cells were separated either by centrifugation or filtration, and 2.5 units of amidase (Sigma-Aldrich) were added to the cellfree solution, which was then incubated for $30 \mathrm{~min}$ at $37^{\circ} \mathrm{C}$. After the solution was transferred to a new test tube, $2 \mathrm{~mL}$ sodium phenate, $3 \mathrm{~mL} 0.01 \%$ sodium nitroprusside solution, and $3 \mathrm{~mL} 0.15 \%$ sodium hydrochloride solution were added, in that order. The tube was vortexed for $30 \mathrm{sec}$ and incubated in the dark at room temperature for $30 \mathrm{~min}$. After $30 \mathrm{~min}$, the OD was measured at $600 \mathrm{~nm}$.

1-Aminocyclopropane-1 carboxylic acid (ACC) deaminase assay. Based upon the method of Nagatsu and Yagi, and using the cell solution prepared above ( $1 \mathrm{mg}$ cells $/ \mathrm{mL}), 1 \mathrm{~mL}$ of cell solution was added to $9 \mathrm{~mL}$ of ACC solution (100 ppm in phosphate buffer) and vigorously mixed for $2 \mathrm{~min}$ at $30^{\circ} \mathrm{C}$. The reaction was then terminated by the addition of $20 \mu \mathrm{L}$ of $4 \mathrm{~N} \mathrm{H}_{2} \mathrm{SO}_{4} .^{13}$ After mixing for $1 \mathrm{~min}$, the reaction was neutralized with $4 \mathrm{~N}$ $\mathrm{NaOH}$. Cells were separated either by centrifugation or filtration, and 2.5 units of amidase (Sigma-Aldrich) were added to the cell-free solution, which was then incubated for $30 \mathrm{~min}$ at $37^{\circ} \mathrm{C}$. The solution was then transferred into a new test tube, and $2 \mathrm{~mL}$ sodium phenate, $3 \mathrm{~mL} 0.01 \%$ sodium nitroprusside solution, and $3 \mathrm{~mL} 0.15 \%$ sodium hydrochloride solution were added, in that order. The test tube was vortexed for $30 \mathrm{sec}$ and incubated in the dark at room temperature for $30 \mathrm{~min}$. After $30 \mathrm{~min}$, OD was measured at $600 \mathrm{~nm}$.

$\beta$-cyanoalanine synthase assay. Based upon the method of Ezzi and Lynch, $1 \mathrm{~mL}$ of the cell suspension $(1 \mathrm{mg} / \mathrm{mL})$ was added to $1 \mathrm{~mL} 50 \mathrm{mM}$ phosphate buffer (pH 7.4). Subsequently, $0.5 \mathrm{~mL}$ of $0.05 \mathrm{M} \mathrm{HCN}$ (in $0.1 \mathrm{M}$ Tris- $\mathrm{HCl}, \mathrm{pH} 8.5$ ) and $0.5 \mathrm{~mL}$ of $0.01 \mathrm{M}$ L-cysteine solution (in $0.1 \mathrm{M}$ Tris- $\mathrm{HCl}, \mathrm{pH} 8.5$ ) were added. $^{14}$ The solution was then immediately capped and incubated at $30^{\circ} \mathrm{C}$ for $20 \mathrm{~min}$. The cells were removed by centrifugation at $13,000 \mathrm{rpm}$ for $2 \mathrm{~min}$. The supernatant was transferred to a new 


\section{PIERCE ET AL.}

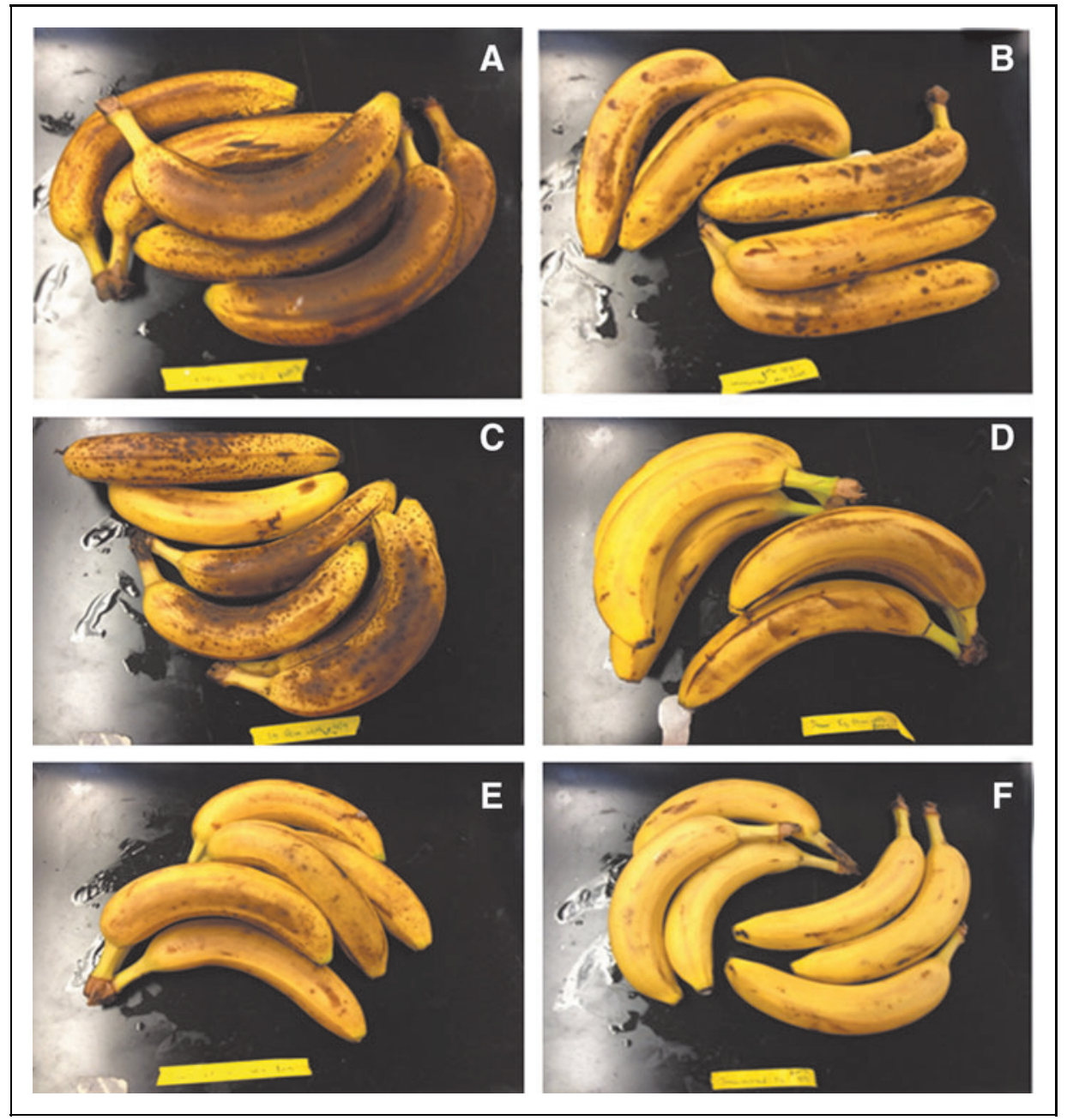

Fig. 3. Yellow-ripe bananas placed with a certain amount of live and immobilized fermented cells in a sealed plastic box for $14 \mathrm{~d}$. (A) Control (bananas only); (B) bananas with immobilization materials (no cells); (C) bananas with $1 \mathrm{~g}$ live fermented cells; (D) bananas with $5 \mathrm{~g}$ live fermented cells; (E) bananas with GA-PEI immobilized cells from $1 \mathrm{~g}$ live fermented cells; (F) bananas with GA-PEI immobilized cells from $5 \mathrm{~g}$ live fermented cells. Cell weights were packed whole cells. then mixed for $1 \mathrm{~min}$ and allowed to rest for $7 \mathrm{~min}$. The OD was read at $520 \mathrm{~nm}$.

Monooxygenase and epoxide hydrolase. Based upon the method of McCay et al., styrene oxide stock solution $(10 \mathrm{mM})$ was prepared by adding $2.85 \mu \mathrm{L}$ of styrene oxide to $2.5 \mathrm{~mL}$ acetone. ${ }^{17}$ Standards of 1 , $2,3,4$, and $5 \mathrm{mM}$ were then prepared in acetone. Then $50 \mu \mathrm{L}$ of each standard was added to $5 \mathrm{~mL}$ of phosphate buffer (50 mM, pH 7). Cell suspension $(0.1 \mathrm{~g} /$ $\mathrm{mL})$ in phosphate buffer $(50 \mathrm{mM}, \mathrm{pH} 7)$ was transferred to a $40-\mathrm{mL}$ amber glass vial (outer vial); $100 \mu \mathrm{mol}(11.5 \mu \mathrm{L})$ of styrene was added to each sample. For assaying epoxide hydrolase, $350 \mu \mathrm{L}$ of $3 \mathrm{mmol} / \mathrm{L}$ of styrene oxide solution was added to each sample. Next, $500 \mu \mathrm{L}$ of 4-(4nitrobenzyl) pyridine solution $(100 \mathrm{mmol} /$ $\mathrm{L})$ in ethylene glycol was added to a 4-mL transparent glass vial (inner vial), which was then placed into the outer vial. The outer vial was crimp-sealed using a crimp with a Teflon-faced butyl rubber septum. The sealed vials were incubated at $30^{\circ} \mathrm{C}$ and $150 \mathrm{rpm}$ for $24 \mathrm{~h}$. To each inner vial $500 \mu \mathrm{L}$ of triethylamine solution $(1: 1 \mathrm{v} / \mathrm{v})$ in acetone was added. The OD was read at $600 \mathrm{~nm}$.

Monooxygenase gas chromatography method. Head-space gas $(500 \mu \mathrm{L})$ was injected into a DB 624 column $(75 \mathrm{~m} \times$ $0.53 \mathrm{~mm}$ ). A Perkin Elmer (Waltham, MA) gas chromatograph, with inlet and flame ionization detector set to $250^{\circ} \mathrm{C}$, was run isothermally at $180^{\circ} \mathrm{C}$ with carrier gas (He) set to $4 \mathrm{~mL} / \mathrm{min}$. tube, to which $0.5 \mathrm{~mL}$ of $0.03 \mathrm{M} \mathrm{FeCl}_{3}$ in $1.2 \mathrm{M} \mathrm{HCl}$ was added followed by rapid addition of $0.5 \mathrm{~mL}$ of $0.02 \mathrm{M} \mathrm{N}, \mathrm{N}$-dimethyl-pphenylenediamine sulfate solution (in $7.2 \mathrm{M} \mathrm{HCl}$ ). The capped samples were incubated at room temperature in the dark for $25 \mathrm{~min}$. The absorbance of each was then read at $600 \mathrm{~nm}$.

Isocitrate lyase. Based upon assays performed by McFadden and Howes, and modifications by Hiller and Charnetzky, $0.1 \mathrm{~mL}$ of cell suspension-1 mg cell/ $0.1 \mathrm{~mL}$ in 3-(N-morpholino)propanesulfonic acid buffer ( $\mathrm{pH} 7.7$ ) containing $5 \mathrm{mM} \mathrm{MgCl}_{2}+$ $1 \mathrm{mM}$ ethylenediaminetetraacetic acid-was incubated with $5 \mathrm{~mL}$ of $2.2 \mathrm{mM}$ isocitric acid for $30 \mathrm{~min}$ at $30^{\circ} \mathrm{C} .{ }^{15,16}$ The cells were then removed by centrifugation at $42,000 \mathrm{rpm}$ for $5 \mathrm{~min}$, and $0.5 \mathrm{~mL}$ of the supernatant was transferred to a test tube, to which $1.0 \mathrm{~mL}$ of $1 \%$ phenylhydrazine hydrochloride solution was added and mixed for $30 \mathrm{sec}$. Concentrated $\mathrm{HCl}(4 \mathrm{~mL})$ was then added, followed by $1 \mathrm{~mL} 5 \% \mathrm{~K}_{3} \mathrm{Fe}(\mathrm{CN})_{6}$. The solution was

\section{Results}

INDUCED $R$. RHODOCHROUS DAP 96253 AND DELAYED RIPENING OF CLIMACTERIC FRUIT

Figures 2 and 3 provide images of delayed ripening of peaches and bananas, respectively. In the comparative images in Fig. 2, a catalyst derived from induced cells of $R$. rhodochrous DAP 96253 was formulated with an edible wax. This wax/catalyst formulation was applied to the inner surface of a standard, commercial peach box; the control box was only wax-coated. The peaches were Big Red Variety from Georgia. (This type of test has been repeated over several seasons). To date, seven different commercial varieties of peaches from Georgia and South Carolina have been evaluated with similar results. In Fig. 3, yellow-ripe bananas were placed in a container alongside a petri dish containing the catalyst derived from the induced cells of $R$. rhodochrous DAP 96253. In the container experiments, yellow-ripe bananas have been 
evaluated as single fingers, multiple-single fingers, and as hands with up to eight fingers. All bananas evaluated originated in South America.

\section{INDUCED $R$. RHODOCHROUS DAP 96253 AND THE POTENTIAL RELATIONSHIP TO THE YANG CYCLE}

The biosynthesis of ethylene in plants (Yang Cycle) is shown in Fig. 1. The precursor to ethylene in the Yang Cycle is ACC. Induced cells of $R$. rhodochrous DAP 96253 possess increased levels of ACC deaminase (Table 1), enabling these cells to convert ACC to $\alpha$-ketobutyric acid and ammonia. In the Yang Cycle, the biosynthesis of ethylene results in the equi-molar production of $\mathrm{HCN}$ and $\mathrm{CO}_{2}$. In plants, the conversion of $\mathrm{HCN}$ to a nontoxic molecule can be accomplished through the action of $\beta$-cyanoalanine synthase $(\beta$-CAS $) .{ }^{18}$ While there are typically several substrates in plants for this reaction, $\beta$-CAS is most often depicted as involving the conversion of methionine to $\beta$ cyanoalanine. Several routes from $\beta$-cyanoalanine are possible, including the production of phytoallexins or the conversion to asparagine. Induced cells of $R$. rhodochrous DAP 96253 possess both cyanidase and a $\beta$-cyanoalanine synthase-like enzyme (Table 1). In addition, induced cells of $R$. rhodochrous DAP 96253 contain very high levels of NHase, which is capable of converting $\beta$-cyanoalanine to asparagine.

A role for monooxygenase(s)? Catalysts derived from either induced viable cells or immobilized induced cells (where the immobilization has rendered the cells non-replicating) are capable of delaying the ripening of climacteric fruit. Direct headspace analysis has confirmed monooxygenase-like activity against ethylene and the subsequent epoxide hydrolase activity. Spiking with styrene and styrene epoxide has confirmed monooxygenaselike activity and epoxide hydrolase activity levels.

Subsequent aerobic experiments with yellow-ripe bananas and induced cells of $R$. rhodochrous DAP 96253 using gasliquid chromatography with direct injection of the head-space (GLC-HS) positively identified a decrease in ethylene and concomitant increase in ethanol.

Observing delayed ripening with a catalyst containing ostensibly dead cells presents a quandry. While investigating the proteins that are altered in abundance in induced cells of
$R$. rhodochrous DAP 96253, we uncovered a protein that upon analysis of fragments obtained through matrix-assisted laser desorption/ionization tandem time of flight (MALDI-TOF-TOF) mass spectrometry has been putatively identified as an oxidoreductase bearing a very high degree of identity to the N,Ndimethyl-4-nitrosoaniline (dependent) oxido-reductase, which was reported by Ohhata et al. to be increased by 20-100-fold in the extreme oligotroph $R$. erythropolis N9T-4 when grown on tetradecane oligotrophically. ${ }^{19}$ Luque-Almagro et al. recently indicated that for the cyanide-degrading pseudomonad $P$. pseudoalcaligenes CECT 5344, HCN combines with oxaloacetate to form the corresponding cyanohydrin. ${ }^{20}$ The cyanohydrin is then deaminated in a stepwise fashion through the aldehyde to the corresponding hydroxy-acid by nitrile hydratase/amidase. Oxalacetate is especially noteworthy, as this compound will form cyanohydrin at room temperature over a $\mathrm{pH}$ range of 6.5-9.5. The cyanohydrin also forms at ambient conditions with $\alpha$-ketoglutarate.

Luque-Almargro et al. further noted that when $P$. pseudoalcaligenes was exposed to cyanide there was a significant increase in the enzyme isocitrate lyase. ${ }^{20}$ Isocitrate lyase is the key enzyme for initiating the glyoxylate bypass. The glyoxylate bypass permits the use of $\mathrm{C}_{2}$ compounds as energy sources. This includes fatty acids and alkanes that degrade via beta-oxidation, producing acetyl CoA.

In separate experiments, the published sequence for the amo-C gene of ammonia monoxygenase (AMO) was used to make a knockout of the homologous AMO in $R$. rhodochrous DAP 96253. AMOs are members of the copper membrane monooxygenase (CuMMOs) family. While the amo- $C$ knockout showed reduced delayed ripening activity, the knockout still retained significant activity $(50 \%)$.

In examining protein gels of induced cells of $R$. rhodochrous DAP 96253, we have confirmed-through excision of this protein and subsequent sequence analysis by MALDI-TOF$\mathrm{TOF}$ - the presence of an alkene monooxygenase. (Alkene monooxygenases do not belong to the CuMMO family). This finding confirms that $R$. rhodochrous DAP 96253 has at least two distinct monooxygenases.

A role for fruit volatiles? That ethylene plays a major role in the ripening of climacterics is well recognized. It has been

\begin{tabular}{|c|c|c|c|c|c|c|c|}
\hline & NHase & AMIDASE & CYANIDASE & ACC DEAMINASE & $B$ (AS-LIKE) & ISOCITRATELYASE & OXIDO-REDUCTASE \\
\hline $\begin{array}{l}\text { R. erythropolis } \\
\text { ATCC } 47072\end{array}$ & 0 & 12 & 7 & 7 & 22 & $N D^{b}$ & ND \\
\hline $\begin{array}{l}\text { R. rhodochrous } \\
\text { DAP } 96622\end{array}$ & 40 & 9 & 7 & 7 & 14 & ND & ND \\
\hline $\begin{array}{l}\text { R. rhodochrous } \\
\text { DAP } 96253\end{array}$ & 210 & 28 & 8 & 15 & 8 & 48 & present \\
\hline
\end{tabular}

aExcept for isocitrate lyase, all units are $\mu$ moles $/ \mathrm{min} / \mathrm{mg}$-cell dry weight. For isocitrate lyase, units are $\mathrm{nmoles} / \mathrm{min} / \mathrm{mg}$-cell dry weight;

${ }^{\mathrm{b} N D}=$ not determined 


\section{PIERCE ET AL.}

suggested that the rate of respiration and ethylene production together profoundly affect ripening in harvested climacteric fruit. $^{3,4,21}$ It is further noted that cyanide insensitive respiration contributes to this increase in respiration. ${ }^{22-24}$ The events of system 2 ethylene biosynthesis influence the aromatic (flavor and fragrance) chemicals, which are distinctive to many climacteric fruit. ${ }^{3}$ For example, the distinctive flavor and aroma compounds have been defined for bananas, apples, and peaches. ${ }^{25-28}$

It is equally true that distinctive volatiles also may affect ethylene biosynthesis; jasmonates represent such an example. Liu et al. showed that increased jasmonate concentrations resulted in increased ethylene biosynthesis in tomatoes. ${ }^{29}$ Fan et al. showed that jasmonate concentrations would influence the aroma chemicals in tomatoes and also in apples. ${ }^{30}$ Subsequently, Zhang et al. showed that the cold storage temperature regime (up to 3 weeks and then up to 3 days after return to ambient) used for storing peaches also influenced the aroma chemicals of the peaches. ${ }^{31}$

Wasternack suggested that in the case of the jasmonates, the metabolic fate was influenced by the many alternate pathways and the concentration of key components. $^{32}$ The complexity of the alternate pathways available are clearly shown by Sanchez et al. in peaches. ${ }^{28}$ Soto et al. have shown that methyljasmonates interfere with ethylene and auxin biosynthesis in peaches. ${ }^{33}$ Earlier, Koch et al. had shown that the biosynthesis of cis-jasmone relieved the stress jasmonate. ${ }^{34}$

Notwithstanding that the bulk of our experiments with climacteric fruit involved catalysts placed in proximity to fruit - and thus in these experiments the ability of the catalyst to react to plant molecules is essentially limited to volatile plant molecules, where the catalyst and fruit are near-the reactivity of the catalyst is no longer limited to volatile chemicals. Members of the Mycolata, including Rhodococcus, Nocardia, and Mycobacterium, are well known for their biotransformation potential, as evidenced in both the scientific and patent literature.

In parallel experiments with yellowripe bananas exposed to induced cells of $R$. rhodochrous DAP 96253, the headspace was analyzed using both direct head-space analysis onto GLC and solid-phase microextraction (SPME) fibers that were desorbed onto the GLC column. Figure 4 shows changes in the (C) stage 7. volatiles of yellow bananas during ripening. In Fig. 5, the GLC head-space profile of induced cells (Fig. 5a) and stage 4,yellowripe bananas (Fig. 5b) are provided. Figure $5 c$ shows the headspace profile of identical stage 4 bananas when exposed to the induced $R$. rhodochrous DAP 96253 cells. Figure 5c shows a significant reduction $(70-90 \%)$ of the major banana volatiles present. This reduction is more clearly shown in Table 2, in which the component concentrations of the major peaks are compared. Figure $5 d$ and Table 2 show the effect on banana

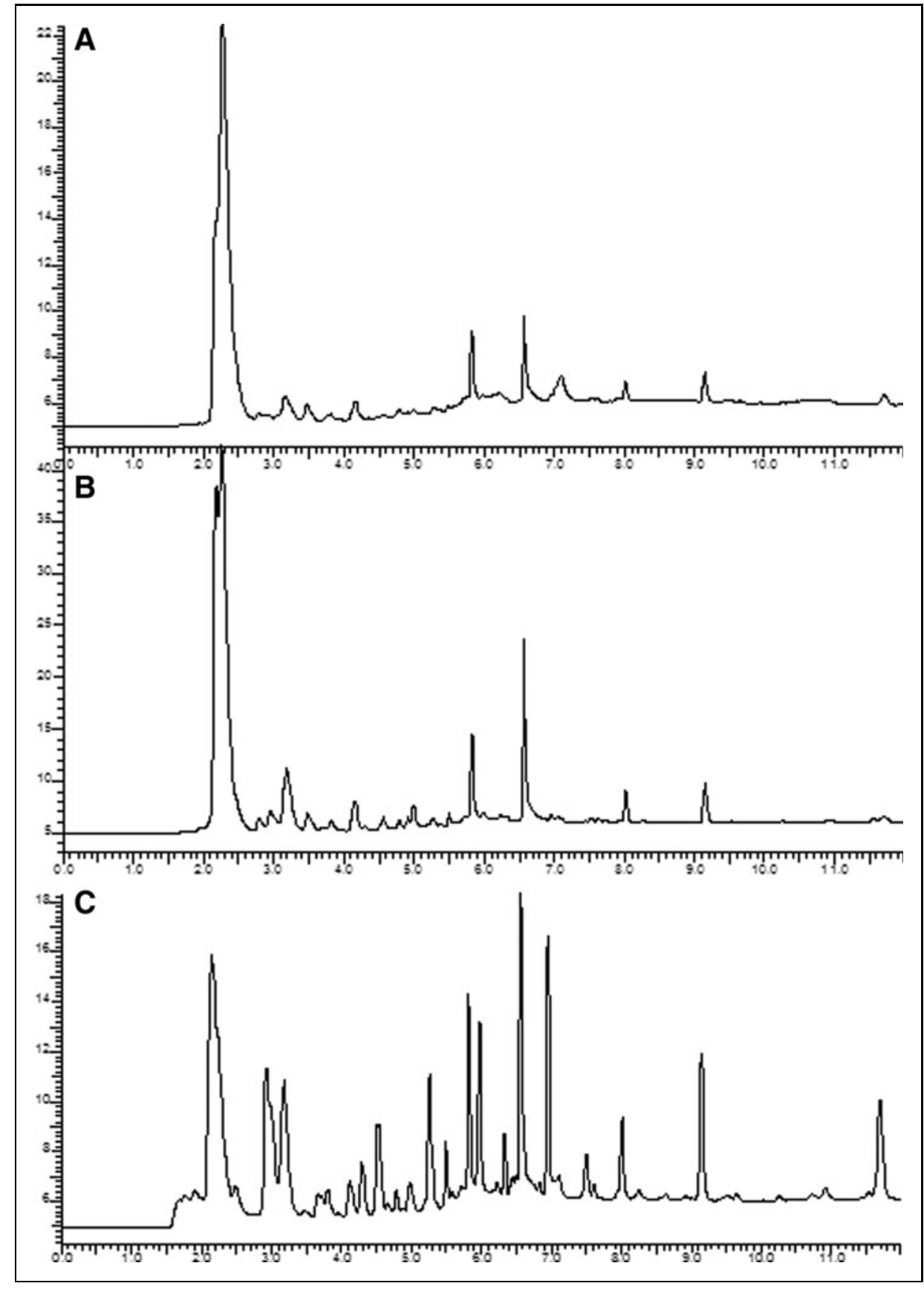

Fig. 4. Comparison of volatiles (by GLS-HS) of yellow-ripe bananas. (A) stage 4; (B) stage 5; 


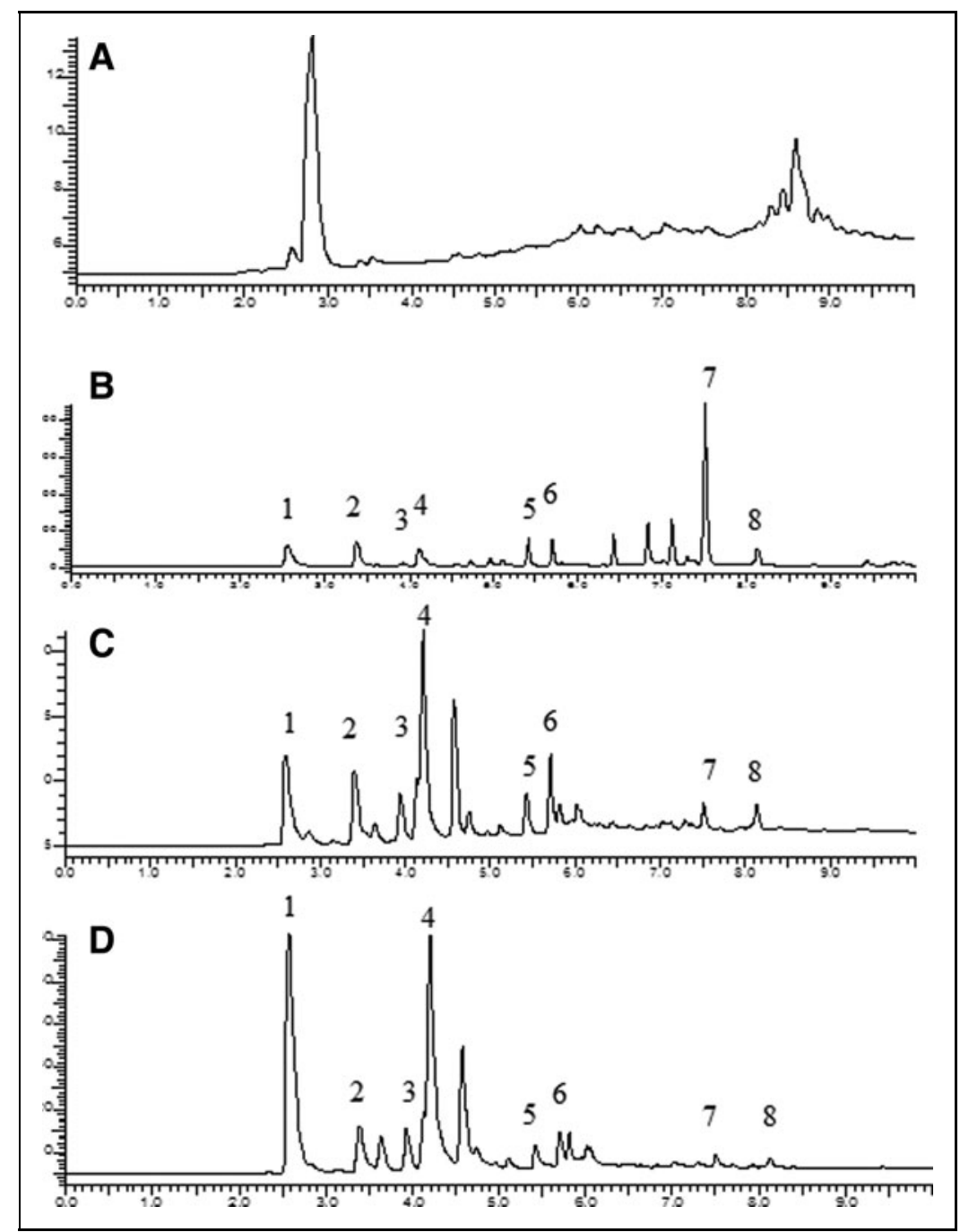

Fig. 5. Comparison of volatiles by GC-SPME. (A) Volatiles of induced $R$. rhodochrous DAP 96253; (B) volatiles of stage 4 yellow ripe bananas; (C) volatiles of Stage 4 yellow ripe bananas in the presence of induced cells of $R$. rhodochrous DAP 96253; (D) volatiles of stage 4 yellow-ripe bananas in the presence of partially induced cells of $R$. rhodochrous DAP 96253. (Chromatograms are aligned by retention time, but concentration scales are different.) volatiles when partially induced cells of $R$. rhodochrous DAP 96253 were used.

These experiments were conducted in triplicate, on three separate occasions with bananas from the same source and same stage (by visual comparison to commercial banana stage rating). Experiments are currently underway with fruit using different varieties and different harvest lots to expand our understanding of catalyst activity with fruit volatiles.

In the initial thinking regarding the metabolism of the products of ethylene biosynthesis (ethylene and cyanide), the combination of $\mathrm{HCN}$ and ethylene epoxide to form the cyanohydrin would result in a product that could easily be metabolized by NHase and amidase to the corresponding acid and ammonia. This approach does not involve molecular oxygen and is, therefore, both oxygen and cyanide insensitive.

Delayed ripening benefits of $R$. rhodochrous DAP 96253 (as well as the countering effects of chill injury, mechanical injury, etc.) may be viewed as being accomplished by the following mechanism (Fig. 6):

- The presence of monooxygenases capable of converting ethylene to the corresponding epoxide, and the subsequent hydrolysis of the ethylene epoxide by epoxide hydrolase; AMOs are oxygen indifferent (provided the reduced pyridine nucleotide cofactor can be regenerated) and do not require molecular oxygen. Using the longer-life styrene we noted both epoxide formation and hydrolysis by $R$. rhodochrous, and our protein analysis and sequencing confirm the presence of an oxido-reductase in induced cells of $R$. rhodochrous DAP 96253. While preliminary in nature and confirmation and validation are required, this is most intriguing.

- We note the increase of isocitrate lyase in cells exhibiting delayed fruit ripening. This is confirmed in gels of cells exhibiting delayed ripening versus cells that do not exhibit delayed ripening.

Table 2. Comparison of the Major Head-Space Volatile (SPME) Constituent Concentrations Shown in Fig. 5B-D
for Bananas in the Presence of Induced Cells or of Partially Induced Cells ${ }^{\mathbf{b}}$
\begin{tabular}{|l|c|c|c|c|c|c|c|c|}
\multicolumn{1}{c|}{ PEAK } & $\mathbf{1}$ & $\mathbf{2}$ & $\mathbf{3}$ & $\mathbf{4}$ & $\mathbf{5}$ & $\mathbf{6}$ & $\mathbf{7}$ & $\mathbf{8}$ \\
\hline Retention time (min) & $\sim 2.6$ & $\sim 3.4$ & $\sim 4.1$ & $\sim 4.2$ & $\sim 5.4$ & $\sim 5.7$ & $\sim 7.5$ & $\sim 8.1$ \\
\hline Bananas only & $100 \%$ & $100 \%$ & $100 \%$ & $7 \%$ & $100 \%$ & $100 \%$ & $100 \%$ & $100 \%$ \\
\hline $\begin{array}{l}\text { Bananas with fully induced } \\
\text { R. rhodochrous DAP 96253 }\end{array}$ & $13 \%$ & $10 \%$ & $5 \%$ & $22 \%$ & $5 \%$ & $104 \%$ & $\sim 0$ & $5 \%$ \\
\hline $\begin{array}{l}\text { Bananas with partially induced } \\
\text { R. rhodochrous DAP 96253 }\end{array}$ & $105 \%$ & $20 \%$ & $15 \%$ & $100 \%$ & $\sim 0$ & $15 \%$ & $1 \%$ & $4 \%$ \\
\hline
\end{tabular}

aSPME, solid-phase microextraction.

${ }^{\text {bC } C o n c e n t r a t i o n ~ o f ~ m a j o r ~ b a n a n a ~ c o n s t i t u e n t s ~ n o r m a l i z e d ~ t o ~} 100 \%$, except for peak 4 . 
PIERCE ET AL.

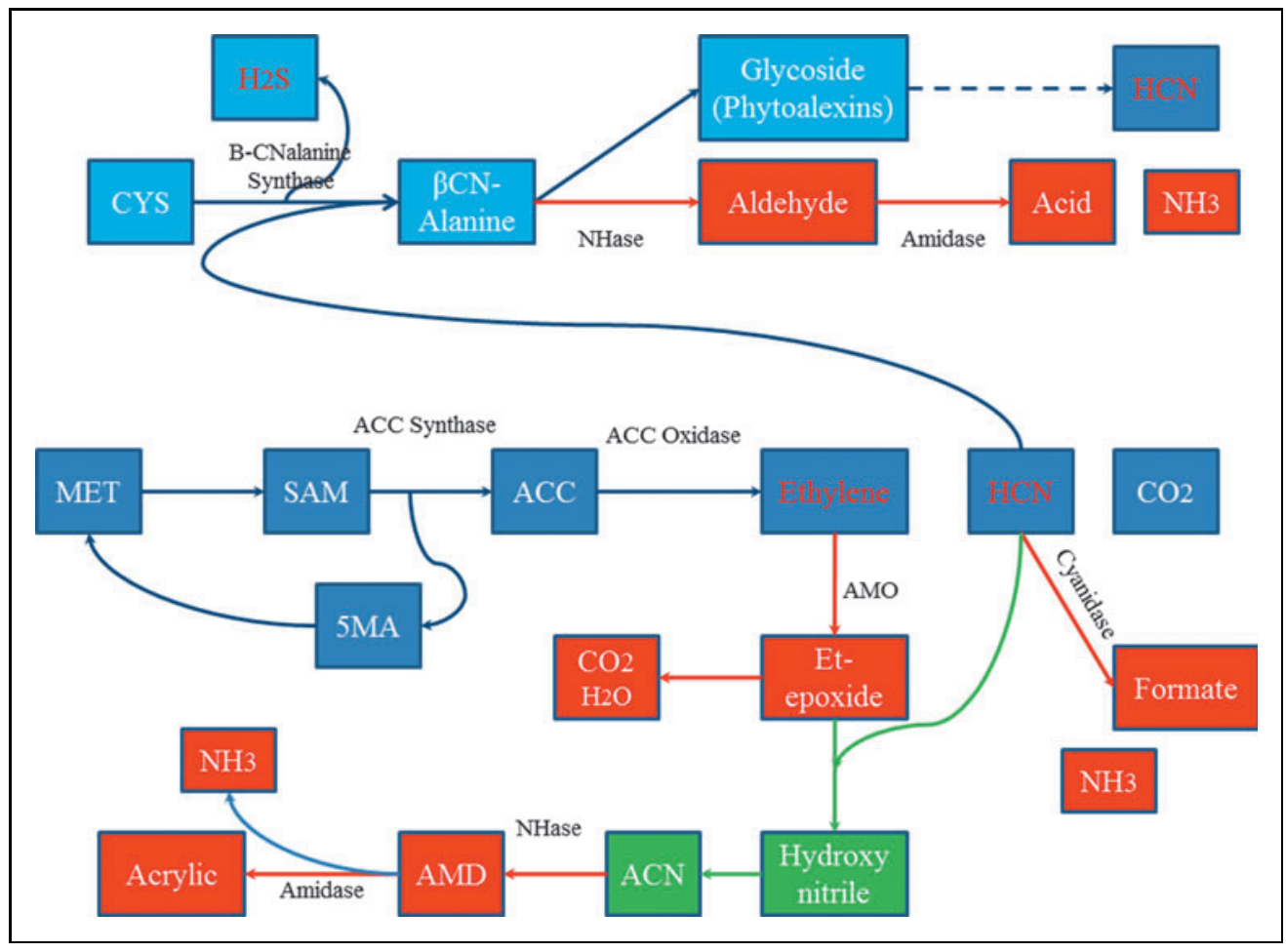

Fig. 6. Yang Cycle with potential mechanisms for the interaction of induced cells of Rhodococcus rhodochrous DAP 96253 (red boxes) with the Yang Cycle in climacteric fruits; green boxes represent potential abiotic mechanisms. ${ }^{1}$

- The creation of the cyanohydrin of oxaloacetate provides a mechanism whereby volatile cyanide can react with oxaloacetate forming the cyanohydrin. We have shown cyanohydrin degradation of cyanoalanine, and acetone cyanohydrin by NHase/amidase. We have previously shown that the NHase in cells grown with cobalt is even more insensitive to cyanide than iron-NHase. We further note that when cells having shown delayed ripening activity

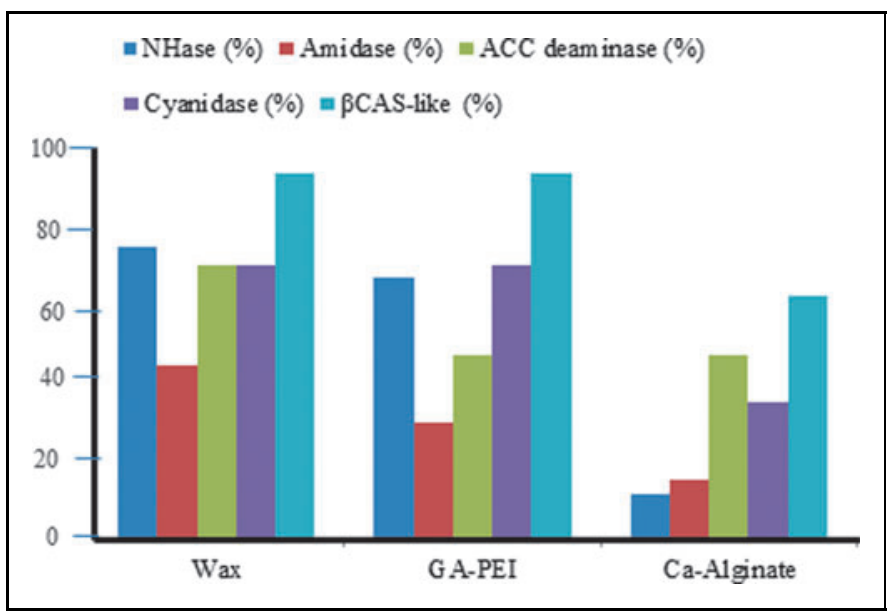

Fig. 7. Effect of edible wax, glutaraldehyde (GA-PEI), and CA-alginate (beads) immobilization on enzyme activity. are exposed to cyanide the cyanide concentrations rapidly fall to undetectable levels.

- Preliminary GLC and mass spectrometry data suggest that, in addition to being able to react with both ethylene and cyanide, the $R$. rhodochrous cells capable of delayed fruit ripening alter the secondary metabolites (e.g., jasmonates) of the ethylene/ cyanide cascade system. Given that these aroma chemicals can influence ethylene biosynthesis, the temporary modification of fruit volatiles could potentially influence ethylene biosynthesis.

If the above were to be confirmed, it would suggest that reducing ethylene to very low levels may not be the sole prerequisite for delayed fruit ripening. By partially reacting with ethylene, and by reacting with cyanide, and by further reducing the secondary metabolites of the ethylene cascade system, ripening management can be affected.

A role for cyanide metabolism? The cyanide metabolism of induced cells of $R$. rhodochrous DAP 96253 is quite robust. In addition, these cells contain $\beta$-cyanoalanine synthase ( $\beta$-CAS) activity. While the levels of $\beta$-CAS in induced DAP 96253 is significantly lower than in the other Rhodococcus strains shown in Table 1, the $\beta$-CAS activity in DAP 96253 is very stable (from $4^{\circ} \mathrm{C}$ to $55^{\circ} \mathrm{C}$ ), and levels of $\beta$-CAS remain essentially constant throughout the experiments with climacteric fruits. In experiments in which the induced cells are simultaneously exposed to both ethylene and cyanide, the cyanide is quickly reduced to undetectable levels.

Catalyst-formulated cell preparations. The stabilization of enzymatic activity of the $R$. rhodochrous DAP cells is a very important practical consideration. Figure 7 shows that calcium alginate immobilized cells have significantly lower enzymatic levels (for the five enzymes selected for evaluation) than immobilization based upon either glutaraldehyde/polyethylenimine crosslinking or immobilization in an edible-wax formulation.

\section{Discussion}

We have consistently shown delayed ripening in peaches (seven commercial varieties from Georgia and South Carolina) and in bananas (yellow-ripe Cavendish bananas). We also have shown significant reduction of chill injury in peaches and in apples (Granny Smith). 


\section{PROKARYOTE-INDUCED DELAYED FRUIT RIPENING}

Our analyses show that fruit in which ripening is delayed can achieve the same level of ripening as that seen in control fruit. In the case of peaches and bananas, our experience has shown that the ripening process can be extended by 7-14 days While we see considerable variability in commercial fruit, we have always seen delayed ripening in those fruit exposed to catalyst derived from induced cells of $R$. rhodochrous DAP 96253.

While we are not at a point in our research where we would categorically state the mechanism of action of delayed ripening, we are struck by the extent to which the biochemistry of $R$. Rhodochrous DAP 96253 overlaps and is integrated into the biochemistry of climacteric fruits. Our perspective has focused on that of the bacteria and the atmosphere of the bacterial-plant microcosm. Future work will reflect that catalyst performance is influenced by the nature and the variety of the fruit.

\section{Acknowledgments}

We wish to thank the following for providing partial support for our research: State of Georgia Department of Agriculture, Georgia Research Alliance (Atlanta), Georgia State University Research Foundation (Atlanta), Georgia State University Office of Research (Atlanta), Georgia Peach Council (Fort Valley), Georgia Fruit and Vegetable Growers Association (LeGrance), and multiple industry sponsors.

\section{Author Disclosure Statement}

All inventions related to the delayed ripening of fruit discussed in this manuscript are the sole property of the Georgia State University Research Foundation. There is no conflict with any commercial entity.

\section{REFERENCES}

1. Yang SF, Hoffman NE. Ethylene biosynthesis and its regulation in higher plants. Annual Rev Plant Physiol 1984;35:155-189.

2. Bleecker $A B$, Kende H. Ethylene: $A$ gaseous signal molecule in plants. Ann Rev Cell Dev Biol 2000;16:1-18.

3. Paul V, Pandey R. Role of internal atmosphere on fruit ripening and storabilityA review. J Food Sci Technol 2014;51(7):1223-1250

4. Paul V, Pandey R, Srivastava GC. The fading distinctions between classical patterns of ripening in climacteric and non-climacteric fruit and the ubiquity of ethylene-a review. J Food Sci Technol 2012;49:1-21.

5. Pierce GE, Drago GK, Ganguly S. Georgia State University Research Foundation.17 May 2011. Biological-based catalyst to delay plant development processes. United States Patent Publication 7,943,549.

6. Pierce GE, Drago GK Ganguly S. Georgia State University Research Foundation. 5 March 2013. Biological-based catalyst to delay plant development processes. United States Patent Publication 8,389,441.

7. Pierce GE, Drago GK, Ganguly S. Georgia State University Research Foundation.17 October 2013. Biological-based catalyst to delay plant development processes. United States Patent Application 2013-0274102.

8. Pierce GE, Drago GK, Ganguly $S$, et al. Preliminary report on a catalyst derived from induced cells of Rhodococcus rhodochrous strain DAP 96253 that delays the ripening of selected climacteric fruit: Bananas, avocados, and peaches. J Ind Microbiol Biotechnol 2011;38:1567-1573.
9. Pierce GE, Drago GK, Ganguly S. Georgia State University Research Foundation. 12 May 2009. Induction and stabilization of enzymatic activity in microorganisms. United States Patent 7,531,343.

10. Pierce GE, Drago GK, Ganguly S. Georgia State University Research Foundation. Induction and stabilization of enzymatic activity in microorganisms. United States Patent 7,531,344.

11. Pierce GE, Drago GK Ganguly S. Georgia State University Research Foundation. 4 December 2012. Method for stabilizing activity of enzymes or microorganism producing the enzymes. United States Patent 8,323,942.

12. Dietz A, Thayer DW. In: Dietz A, Thayer DW, eds. Actinomycete Taxonomy (SIM 373 Special Publication No. 6). Arlington, VA: Society for Industrial Microbiology, 1980;227-291.

13. Nagatsu T, Yagi K. A simple assay of monoamine oxidase and D-amino acid oxidase by measuring ammonia. J Biochem 1966;60:219-221.

14. Ezzi M, Lynch JM. Cyanide catabolizing enzymes in Trichoderma spp. Enz Microb Technol 2002;31:1042-1047.

15. McFadden BA, Howes WV. The determination of glyoxylic acid in biological systems. Anal Biochem 1960;1:240-248.

16. Hiller SL, Charnetzky WT. Rapid diagnostic test that uses isocitrate lyase activity for identification of Yersinia pestis. J Clin Microbiol 1981;13:661-665.

17. McClay KB, Fox BG, Steffan RJ. Toluene monooxygenase-catalyzed epoxidation of alkenes. Appl Environ Microbiol 2000;66:1877-1882.

18. Watanabe M, Kusano M, Oikawa A, et al. Physiological roles of the betasubstituted alanine synthase gene family in Arabidopsis. Plant Physiol 2008;146:310-320.

19. Ohhata N, Yoshida N, Egami H, et al. An extremely oligotrophic bacterium, Rhodococcus erythropolis N9T-4, isolated from crude oil. J Bacteriol 2007;189:6824-6831.

20. Luque-Almagro VM, Merchan F, Blasco R, et al. Cyanide degradation by Pseudomonas pseudoalcaligenes CECT5344 involves a malate: Quinone oxidoreductase and an associated cyanide-insensitive electron transfer chain. Microbiology 2011;157:739-746.

21. Golding JB, Shearer D, McGlassen WB, Wylie SG. Relationship between respiration, ethylene and aroma production in ripening bananas. J Agric Food Chem 1999;47:1646-1651

22. Kumar S, Sinha SK. Alternative respiration and heat production in ripening banana fruits (Musa paradisiacal var. Mysore Kadali). J Exp Bot 1992;43:16391642.

23. Pandey R, Zeng Y, Prasad NK, Srivastava GC. Alternate respiration during ripening of tomato fruits. Indian J Plant Physiol 1995;3:94-96.

24. Reddy Y, Srivastava GC. Ethylene biosynthesis and respiration in mango during ripening. Indian J Plant Physiol 1999;4:32-35.

25. Jordan MJ, Goodner KL, Shaw PE. Volatile components in banana (Musa accuminatacolla cv. Cavendish) and yellow passion fruit (Passiflora edulis simsF. Flavicarpa Degner) as determined by GC-MS and GC-olfactometry. Proc Fla State Hort Soc 2001;114:153-157.

26. Dixon J, Hewett EW. Factors affecting apple aroma/flavor volatile concentration: A review. New Zealand J Crop Horticult Sci 2000;28:153173.

27. Eduardo I, Chietera G, Bassii D, et al. Identification of key odor volatile compounds in the essential oil of nine peach accessions. J Sci Food Agric 2010;90:1146-1154.

28. Sanchez G, Besada C, Badenes ML, et al. A non-targeted approach unravels the volatile network in peach fruit. PLoS One 2012;7(6):e38992.

29. Liu L, Wei J, Zhang M, Zhang L, et al. Ethylene independent induction of lycopene biosynthesis in tomato fruits by jasmines. J Exp Bot 2012;63:57515761.

30. Fan $X$, Matheis JP, Fellman JK. A role for jasmonates in climacteric fruit ripening. Planta 1998;204:444-449. 


\section{PIERCE ET AL.}

31. Zhang B, Xi WP, Wei WW, et al. Changes in aroma-related volatiles and gene expression during low temperature storage and subsequent shelf-life of peach fruit. Post-Harvest Biol Technol 2011;60:7-16.

32. Wasternack C. Jasmonates: An update on biosynthesis, signal transduction and action in plant stress response, growth and development. Annals Bot 2007;100:681-697.

33. Koch T, Bandemer K, Boland W. Biosynthesis of cis-jasmone: A pathway for the inactivation and the disposal of the plant stress hormone jasmonic acid to the gas-phase. Helvetica Chimica Acta 1997;80:838-850.

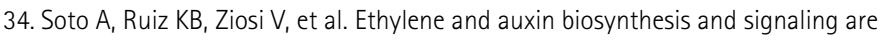
impaired by methyl jasmonate leading to a transient slowing down of ripening in peach fruit. J Plant Physiol 2012;169:1858-1865.
Address correspondence to: George E. Pierce, PhD

Professor

Applied \& Environmental Microbiology

Department of Biology

Georgia State University

24 Peachtree Center Ave.

Atlanta, GA 30303

Phone: (404) 413-5315

Fax: (404) 413-4302

E-mail: gpierce@gsu.edu 